\title{
Assessing the Changes in Bacterial Diversity in Rhizosphere and Phyllosphere of Transgenic and Non-transgenic Potato Plant
}

\author{
N. Saha ${ }^{1}$, A. Ulrich, R. Becker and S. Wirth \\ Center for Agriculture and Landuse Research; Institute for Primary Production and \\ Microbial Ecology, Muencheberg, Germany
}

Key words: Assement, Bacterial diversity, Rhizosphere, Transgenic, Potato

\begin{abstract}
The present communication deals with the study of changes in bacterial community structure in the rhizosphere and phyllosphere under the influence of transgenic and non-transgenic potato plant. The transgenic potato plants used in this experiment synthesize fructan-soluble carbohydrate in the tuber and gives better nutritive value of different biological importance. To assess the changes in bacterial diversity, terminal restriction fragment length polymorphism (T-RFLP) - a fingerprint technique, based on terminal restriction fragment length polymorphism between distinct small-subunit rDNA gene sequence, was used. Three lines of genetically modified (GM) potato (modified from variety-Desiree), one genetically unmodified control (GUM, variety-Desiree) and one traditional potato variety (Linda), were used and sampling was done at full growth stage of potato. Total microbial DNA from rhizosphere and phyllosphere samples was isolated, amplified the $16 \mathrm{~S}$ rDNA gene for bacterial community with fluoresecence tag primer pair and digested with restriction enzyme HhaI. The digested products were run along with DNA-length standard 100 ROX in an automated genescaner. The T-RFLP analysis resulted in very complex and highly reproducible community fingerprints patterns and showed no clear difference in the bacterial diversity among the rhizosphere of GM, GUM and traditional potato variety. On the other hand, phyllosphere bacterial diversity gave different trend between transgenic and non-transgenic plants. However, the T-RFLP patterns of phyllosphere bacterial community of three GM potato varieties were similar. The same was completely different between GUM and traditional potato varieties.
\end{abstract}

\section{Introduction}

Plants are the primary source of life in soil. They provide necessary nutrients, protection, and determine the microclimate for soil organisms in the uppermost soil layers. Plants, therefore, have a big influence on the size and composition of

\footnotetext{
${ }^{1}$ AICRP on Soil Test Crop response Correlation, Directorate of research, Bidhan Chandra Krishi

Viswavidyalaya, Mohanpur, Nadia, WB. 741252. India
} 
the microbial community and the distribution of microorganisms. Microorganisms are the dominant soil organisms accounting for over $80 \%$ of the total biomass of most soil ecosystems. They largely determine the functioning of terrestrial ecosystems, and they have direct interactions with plants, thereby creating a strong feedback between plants and microorganisms. There is a global hypothesis that the upper ground biodiversity controls the below ground diversity. So the genetic make-up of plants has an influence on the community structure of soil microbes. In this regard the study of the effects of genetically modified plants (GMP) on the diversity of microbes in soil will be worthy to predict the possible risk associate with the field cultivation of GM crops. To date environmental risk assessments regarding the cultivation of GMP have mainly focused on the above ground effects (Bruinsma et al. 2002). But soil microorganisms have every possibility to be exposed to the undesired effects of GMP through the route of root exudates, slough-off tissues and decomposition of crop residues in soil. This may jeopardize the biosafety depending on the route and times exposure. Another major public concern is the possibility for horizontal gene transfer (HGT), whereby the genetic material that is introduced into the GMP is non-sexually transferred to other organisms (Kidwell 1993, Droege et al. 1998). In field level, though the frequency of transfer of recombinant gene from plants to soil-borne bacteria is less (Droege et al. 1998, Hoffmann et al. 1994). However, the expression of the acquired genes and the subsequent selection pressure (of surrounding environment) on the host species might be of more importance in determining the consequences of HGT between GMPs and soil microbes (Nielsen et al. 2001).

Biotechnology has great potential to advance agricultural practices (Anonymous 2003). However, the creation and use of GMPs is a controversial issue. Supporters argue that genetic modification is indispensable to meet the food demands of the world's increasing population, especially in the Third World. After the invention of transgenic plants, many desired traits had been introduced into the economically important crops (Tsaftaris et al. 2000). Most current research in this field is directed toward the improvement of food crops such as potatoes, maize sugar beets as well as oilseed crops like soyabean and canola (Min et al. 2005, Miling et al. 2005, Reddy et al. 2003, Anonymous 2005 ).

Potato is one of the most important economic crops all over the world. It is staple food in many European and American countries. In Third world's countries, it has been used as vegetable. Moreover, this crop has tremendous importance in industrial usage. So the development of this crop is expected. But possible risk associated with genetic manipulation should be assessed in well advance for protection of soil health. 
Under this background, this investigation was carried out to assess the changes in bacterial diversity if any under the influence of transgenic potato plant.

\section{Materials and Methods}

Field trials: Field trials were conducted at the Institute of Primary Production, division of Microbial Ecology, Center for Agriculture and Landuse Research; Muencheberg, Germany in 2002. Soils under investigation were planted with different potato plant variants as follows: three lines of genetically modified (GM) potato (modified from variety-Desiree), one genetically unmodified control (GUM, var. Desiree) and traditional potato vars. Linda and Adretta. Different types of potatoes were planted in a randomised plot having dimension of $0.6 \times$ $2.3 \mathrm{~m}$. Standared package of practices were followed to grow the plants.

Transgenic plants: The transgenic potato plants carried two modified gene constructs. One gene construct consists of Saccharose: Saccharose Fructosyltransferase and the other Fructan: Fructan Fructosyltransferase (35S-SST-FFT-22/19, 35S-SST-FFT-22/30 35S-SST-FFT-22/36) from Artichoke (Cynara scolymus). The transgenic potato plants used in this experiment synthesize fructan - a soluble carbohydrate in the tuber and gives better nutritive value of different biological importance (Starch, the storage carbohydrate of traditional potatoe varities, is sparingly soluble. But fructan is completely soluble. So digestibility is comparatively higher. Moreover, it has anticancerous role).

Sampling: To collect both the rhizospheric and phyllospheric bacterial cells, rhizosphere soil and phyllosphere leaves of potato plants were sampled at full growth stage of potato. Healthy plants were uprooted gently. Approximately $15 \mathrm{~g}$ fine root mass along with adhering soils were collected and packed in a polythene packet. Twelve feeder leaves from healthy plant from each plot were collected. Both soil and leaves were transported to laboratory in an icebox.

Harvesting of bacterial cells: Homogenization of bacterial cells from rhizosphere and phyllosphere samples. Bacterial cells from rhizosphere soils were homogenized by various steps. $3 \mathrm{~g}$ root samples were mixed with $30 \mathrm{ml}$ phosphate buffer ( $\mathrm{pH} 7$ ), $3 \mathrm{~g}$ stone chips and $0.4 \mathrm{~g}$ chelex (It is a dispersing agent used to disperse the bacterial cells from rhizosphere soil) and shaked for one hour. Then $15 \mathrm{ml}$ NDP $(0.02 \%$ sodiumdesoxychelate $+0.05 \%$ PEG 6000) was added and was shaked for $15 \mathrm{~min}$.

Bacterial cells from phyllosphere samples were homogenized by cutting the leaves in $0.5 \mathrm{~cm}$ pieces and mixed with $40 \mathrm{ml}$ phosphate buffer and the samples were run for $2 \times 60$ s in Stomacher (It is a lab-blender (Seward Medical, London, United Kingdom. It is used for homogenization ). 
Pelleting the cells: After homogenization of cells, samples were centrifuged at $500 \times \mathrm{g}(2 \mathrm{~min})$ to discard the plant residue. The supernatant was further centrifuged at $5000 \times \mathrm{g}(20 \mathrm{~min})$ to pellet the bacterial cells in samples. Pellets were washed with $0.25 \%$ Ringer solution and again centrifuged at $5000 \times \mathrm{g}(20$ $\mathrm{min}, 4^{\circ} \mathrm{C}$ ). The purified pellets were stocked in $100 \mathrm{ml}$ Ringer Solution (It is a solution containing $22.05 \mathrm{~g} \mathrm{NaCl}, 0.61 \mathrm{~g} \mathrm{Cacl}_{2}, 1.05 \mathrm{~g} \mathrm{KCl}$ and $0.50 \mathrm{~g} \mathrm{NaHCO}_{3}$ for $100 \mathrm{ml}$ solution.) at $-20^{\circ} \mathrm{C}$.

DNA extraction: The stock pellets were used to isolate the DNA. The rhizospheric bacterial DNA was isolated by DNA Spin Kit for Soil (Q BIOgene) whereas the phyllospheric bacterial DNA were extracted by Fast DNA Kit as directed by the manufacturer.

Polymerase chain reaction (PCR) amplification: The bacterial $16 \mathrm{~S}$ rDNA was PCR-amplified from total DNA using oligonucleotide primers which target a wide range of members of the domain Bacteria. The rhizospheric bacterial $16 \mathrm{~S}$ rDNA was amplified with primer pair 27f and 926r (Liu et al. 1997) where as phyllospheric bacterial $16 \mathrm{~S}$ rDNA was amplified with primer pair 799f(AACAC GGATTAGATACCCGTG) and 1525r (AAGGAGGTGATTCCAAGCC) as described by Chelius and Triplett 2001. For Terminal Restriction Fragment Length Polymorphism (T-RFLP) analysis the $5^{\prime}$ primer (27r) was labeled with the dye 5 -carboxyfluorescein. The reaction cocktail contained $1 \mu$ l of template DNA, $5 \mu$ l of $10 \times$ reaction buffer (Applied Biosystem, Weiterstadt, Germany), $3.5 \mu \mathrm{l}$ of $\mathrm{MgCl}_{2}$, $0.5 \mu \mathrm{l}$ of deoxynucleoside triphosphate, $0.25 \mu \mathrm{l}$ of each primer, $0.5 \mu \mathrm{l}$ Taqpolymerase (PE Biosystem) and $39.5 \mu \mathrm{l}$ water. (It is standard laboratory protocol for PCR amplification mentioned here). The thermal PCR profile was as follows: initial denaturation for $4 \mathrm{~min}$ at $94^{\circ} \mathrm{C}$ and 25 cycles consisting of 30s denaturation at $94^{\circ} \mathrm{C}$, primer annealing at $50^{\circ} \mathrm{C}$ for $40 \mathrm{~s}$ and elongation at $72^{\circ} \mathrm{C}$ for $2 \mathrm{~min}$. The final elongation step was extended to $8 \mathrm{~min}$ at $72^{\circ} \mathrm{C}$. Amplification was performed with a total volume of $50 \mu \mathrm{l}$ in $0.1 \mathrm{ml}$ reaction tubes and a DNA thermal cycler (model-2400; Applied Biosystems). Aliquots of the 16S rDNA amplicons $(10 \mu \mathrm{l})$ were checked by electrophoresis on a $1 \%$ agarose gel and stained with ethidium bromide.

T-RFLP analysis: The $16 \mathrm{~S}$ rDNA amplicons were purified using Qiaquick spin columns (Qiagen, Hilden, Germany) according to the instructions of the manufacturer. Aliquots of purified amplicons were digested with the restriction endonuclease HhaI (Promega, Mannheim, Germany). The reaction cocktails contained $2 \mu \mathrm{l}$ of the purified PCR products, $1 \mu \mathrm{l}$ of incubation buffer and $1 \mu \mathrm{l}$ of endonuclease (10U). The digestion was performed with a total volume of $10 \mu \mathrm{l}$ at $37^{\circ} \mathrm{C}$ for $3 \mathrm{~h}$ as suggested by Lukow et al. (2000). Aliquots of the digests $(2.5 \mu \mathrm{l})$ were mixed with $2.0 \mu \mathrm{l}$ of formamide and $0.5 \mu \mathrm{l}$ of an internal lane standard (GeneScan-1000 ROX, PE Applied Biosystems). The samples were denatured at 
$94^{\circ} \mathrm{C}$ for $2 \mathrm{~min}$ and then immediately placed on ice until loading into the gel. Electrophoresis was carried out on a $12 \mathrm{~cm} 6 \%(\mathrm{w} / \mathrm{v})$ polyacrylamide gel containing 8.3-M urea and 1x Tris-borate-EDTA buffer. The restricted 16S rDNA fragments were size separated in relation to the internal lane standard in the GeneScan mode of an automated ABI DNA sequencer (PE Applied Biosystems). Only the fluorescently-labeled 5'-terminal restriction fragments were detected and further analyzed. The length and the fluorescence signal intensity of each $\mathrm{T}-\mathrm{RF}$ in a given community fingerprint pattern were automatically calculated by the "GeneScan Analysis Software" (Version 2.1. PE Applied Biosystems).

\section{Results and Discussion}

The comparative assessment of bacterial diversity between transgenic and nontransgenic potato plants was done by analyzing the number of T-RFs (richness) and their relative abundance (evenness). But a prerequisite for a meaningful comparative analysis of T-RFLP patterns generated from different rhizosphere and phyllosphere samples is high accuracy in the determination of both size and signal intensity of individual T-RFs. The accuracy of automated size determination has been demonstrated (Liu et al. 1997, Mayrand et al. 1992). In our study, highly reproducible T-RFs we have while studying the diversity of bacteria from replicated samples collected from rhizo-phyllosphere of potato plants (Fig. 1).

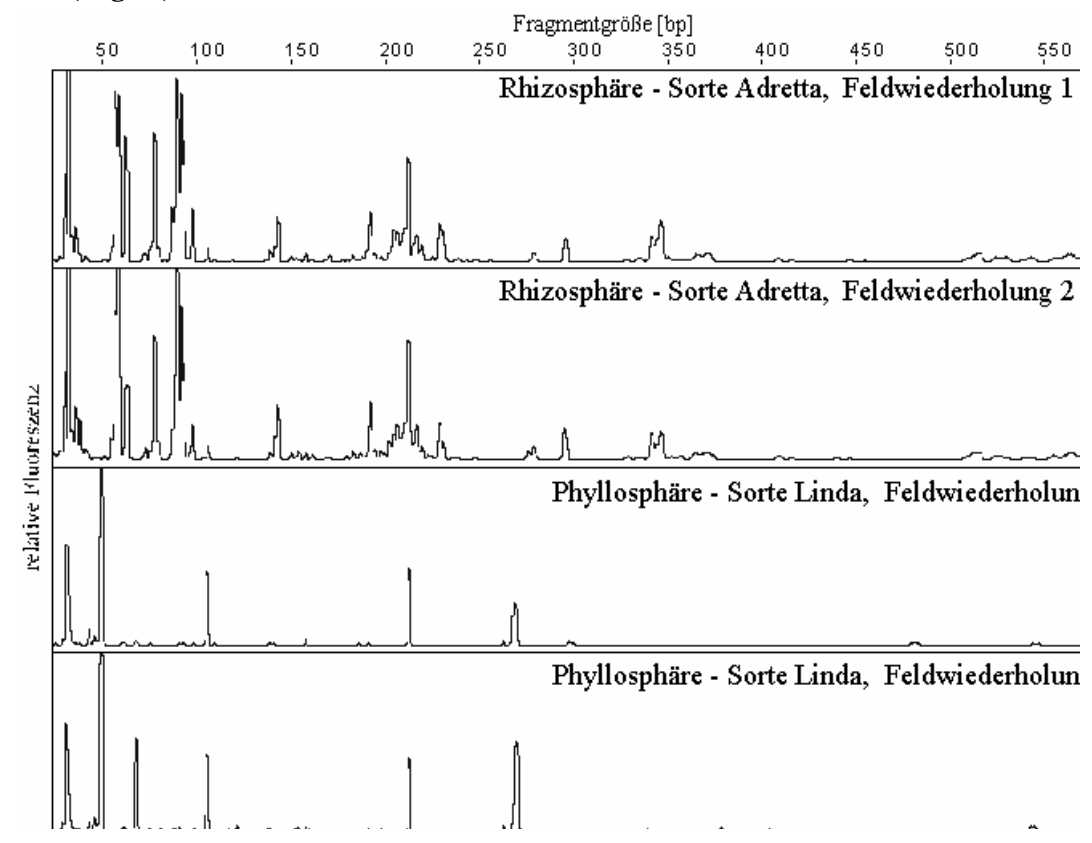

Fig.1. T-RFLP fingerprints pattern of rhizosphere and phyllosphere bacteria of two non-transgenic potato plants. N.B. Here rhizosphare, phyllosphare, sorte, frangmentgrosse and fieldwiederholung mean rhizosphere, phyllosphere, variety, fragment length and field replication, respectively. 
While comparing the $16 \mathrm{~S}$ rDNA-based T-RFLP community fingerprints patterns between rhizo-phyllospheric bacteria of non-transgenic potato plants (vars. Adretta and Linda), it was observed that rhizosphere samples had more number of relatively high T-RFs with higher peak area (Fig. 1). From this result it can be concluded that rhizosphere is rich in bacterial diversity as compared to those of phyllosphere. But when the potato variety Desiree is genetically modified by two gene constructs, namely Saccharose: Saccharose Fructosyltransferase and Fructan: Fructan Fructosyltransferase, still rhizosphere soil sample gives similar patterns of $16 \mathrm{~S}$ rDNA-based T-RFLP fingerprints (Fig. 2).

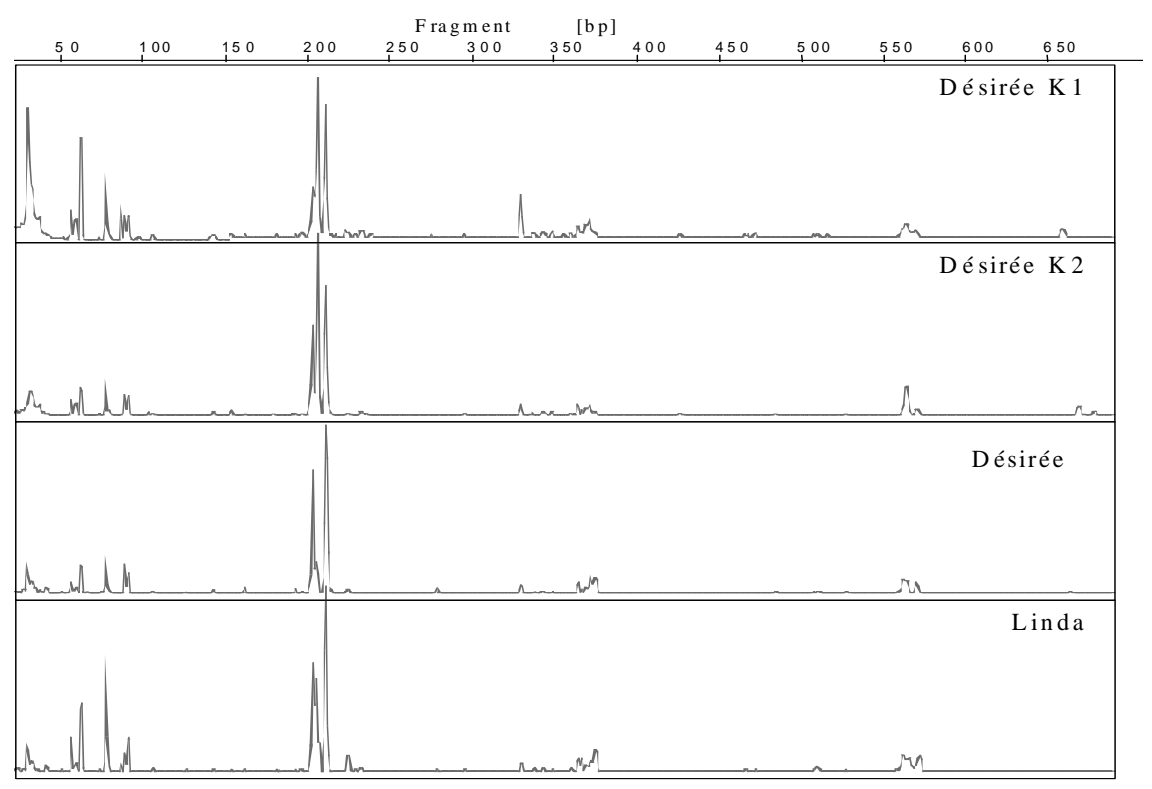

Fig. 2. T-RFLP fingerprints pattern of rhizospheric bacteria of transgenic, non-transgenic and conventional potato plants.

The results thus demonstrated that genetically modification has no remarkable influence in the bacterial diversity in the rhizosphere soils of potato. Even the rhizosphere bacterial diversity of conventional potato var. Linda is very similar to that of transgenic potato. This can be explained by the fact that genetical modification probably does not influence on quality and quantity of root exudates - the primary source of soil bacteria. This corroborated the earlier findings of Reiner et al. (2002), Min et al. (2005), Miling et al. (2005). The authors observed that, changes in diversity are more affected by soil texture than by cultivation of transgenic plants. They also pointed out that natural factors are more responsible to bring about of rhizospheric bacterial communities than that of genetical modification. Moreover, in field level there is a little chance for horizontal transfer of gene (HGT) from GMP to soil bacteria (Nielsen et al. 2000). 
But, genetically modification results in changes in phyllospheric bacterial diversity and gives different patterns of T-RFLP fingerprints while comparing with mother var. Desiree whereas, T-RFLP-based community fingerprints patterns of phyllospheric bacterial community among the three lines of genetically modified potato plants are similar (Fig. 3).

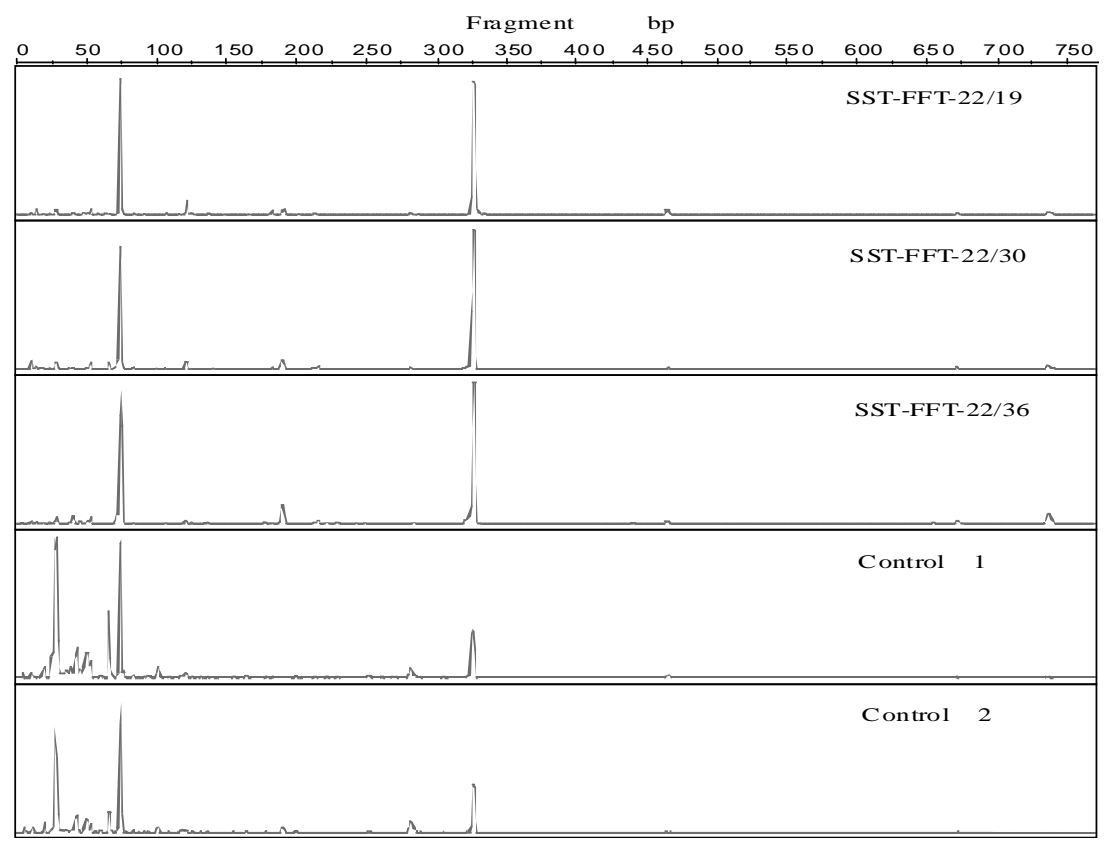

Fig. 3. T-RFLP fingerprints pattern of phyllospheric bacteria of transgenic, non-transgenic and conventional potato plants.

It may be due to modified cuticle and other organic - the primary food sources of leaf bacteria (It is an assumption put forward by the authors. Due to introduction of two genes from Artichoke to potato, the nature of main carbohydrate accumulated in potato has been changed. So, it has been assumed that the nature of cuticle and other leaf exudates may be changed and that may influence on the diversity of phyllospheric bacteria through the route of carbon utilization. Alternatively, gene may be transferred from GMP to leaf bacteria and may cause changes in bacterial diversity.

Results presented here are the outcome of short-term experiment. But monitoring of diversity change requires long-term experiment. So, more researches toward risk assessment for GMP cultivation will be deemed necessary for concrete comments. Perceptible change in the level of species diversity can not be expected in short term experimental results. It requires a long-term experiments of at least 7-10 years. To assess the risk, not only diversity but also other metabolites and the nature of root exudates must be considered. 


\section{Acknowledgement}

The author (NS) gratefully acknowledges the financial assistance offered by

German Govt. (InWEnt-International Capacity Building) to carry out the programme in collaboration with ZALF (Center for Agriculture and Land Use Research, Institute for Primary Production, Muenceberg, Germany) during 20022003.

\section{References}

Anonymous (2003) Shaping the future of agriculture. Agriculture 21. Agricultural and Consumer Protection Department. FAO. Rome.

Anonymous (2005) Impact of Transgenic Canola on Growers, Industry and Environment. Canada Council of Canola. www.canola-council.org.

Bruinsma M, Kowalchuk GA and Van Veen JA (2002) In: Effects of Genetically Modified Plants on Soil Ecosystems. Netherlands Institute of Ecology. Center for Terrestrial Ecology. Heteren, the Netherlands.

Chelius MK and Triplett FW (2001) The diversity of Archaea and Bacteria in the roots of Zea mays L. Microb. Ecol. 41: 252-263

Droege M, Puehler A and Selbitschka W (1998) Horizontal gene transfer as a biosafty issue: A natural phenomenon of public concern. J. Biotechnol. 64: 75-90.

Hoffmann T, Golz C and Schieder O (1994) Foreign DNA sequences are received by a wild type strain of Aspergillus niger after co-culture with transgenic higher plants. Curr. Gen. 27: 70-76.

Kidwell MG (1993) Lateral transfer in natural populations of eucaryotes. Ann. Rev. Gen. 72, 235-256.

Liu WT, Marsh TL, Cheng H and Forney LJ (1997) Characterization of microbial diversity by determining terminal restriction fragment length polymorphisms of genes encoding 16S rRNA. Appl.Environ. Microbiol. 63: 4516-4522.

Lukow T, Dunfield PF and Liesack W (2000) Use of T-RFLP technique to assess spatial and temporal changes in the bacterial community structure within an agricultural soil planted with transgenic and non-transgenic potato plants. FEMS Microbiol. Ecol. 32: 241-147.

Mayrand PE, Corcoran KP, Ziegle JS, Robertson JM, Hoff LB and Kronock MN (1992) The use of fluorescence detection and internal lane standards to size PCR products automatically. Appl. Theor. Electrophor. 3: 1-11.

Miling A, Smalla K and Maidi FX (2005) Effect of transgenic potatoes with an altered starch composition on the diversity of soil and rhizosphere bacteria and fungi. Pl. Soil 266:23-39.

Min F, Kremer RJ, Motavalli PP and Davis G (2005) Bacterial diversity in rhizosphere of non-transgenic and transgenic corn. App. Environ. Microbiol. 71: 4132-4136.

Nielsen KM, Van Elsas JD and Smalla K (2001) Dynamics, horizontal transfer and selection of novel DNA in bacterial populations in the phytosphere of transgenic plants. Annal. Microbiol. 51: 79-94.

Reddy MSS, Dinkins RD and Collins GB (2003) Gene silencing in transgenic soyabean plants transformed via particle bombardment. Pl. Cell. Repo. 21: 676-683. 
Reiner HH, Kropperstedt M, Lottmann J, Berg G and Smalla K (2002) Effect of T4 lysozyme release from transgenic potato roots on bacterial rhizospher communities. App. Environ. Microbiol. 68: 1325-1335.

Tsaftaris AS, Polidoris AN, Karavangeli M, Nianiou-Obeidat I, Madesis $\mathbf{P}$ and Goudoula C (2000) Transgenic crops: recent developments and prospects. Biological Resource management. Balazs, E., Galante, E., Lynch, J.M., Schepers, J.S., Toutant, J.P., werner, D. Werry, P.A. Th. J. (eds.). Springer-Verslag, Berlin. pp.187-203. 